Катарина Р. Полић

Универзитет у Новом Саду

Филозофски факултет

Студент докторских студија

katarina.polic94@gmail.com doi: 10.19090/zjik.2020.27-47

UDK 811.161.1:811.163.41:811.111]'367.625;

$81 ’ 255$

оригинални научни рад

\title{
О ГЛАГОЛСКИМ ЛЕКСЕМАМА СА ПРЕФИКСИМА НА-, НАД- И О- У СРПСКОМ ЈЕЗИКУ И ЊИХОВИМ РУСКИМ И ЕНГЛЕСКИМ ПРЕВОДНИМ ЕКВИВАЛЕНТИМА ${ }^{1}$
}

САЖЕТАК: У раду се анализира семантика глаголских лексема у чијој творбеној структури срећемо префиксе на-, над- и о- у српском језику, а затим се они путем контрастивне анализе упоређују са преводним еквивалентима у руском и енглеском језику. Основу рада чине глаголи прикупљени из романа На Дрини ћуприја, а циљ истраживања је утврђивање у којој мери је адекватан превод глагола са поменутим префиксима у руском и енглеском језику у односу на српски језик, односно да ли су преводиоци приликом превода успели да пренесу све компоненте значења одређених глагола. Циљ рада је и указивање на евентуалне преводне еквиваленте који би успешније пренели значење глагола у други језик. На основу резултата добијених контрастивном анализом дошли смо до закључка који је потврдио полазну хипотезу а то је да је у српском и руском језику, као језицима из исте, словенске групе језика, сличност и подударање знатно веће у односу на енглески језик, као језик из германске групе, у коме су глаголске лексеме са поменутим префиксима изражене синтаксичким конструкцијама и фразним глаголима, а ређе глаголима са префиксима.

Кључне речи: префикси на-, над- и о-, префиксација глагола, српски, руски и енглески језик, контрастивна анализа

\section{1. УВОД}

Предмет рада је контрастивна анализа глаголских лексема српског језика са префиксима на-, над- и о- из романа На Дрини ћуприја Иве Андрића и њихових преводних еквивалента у руском и енглеском језику. У раду је коришћен метод семантичке анализе глаголских лексема са поменутим

\footnotetext{
${ }^{1}$ Рад је дело обимнијег истраживања, насталог под менторством проф. др Предрага Новакова, у оквиру предмета Контрастивна проучавања језика (енглеско-српска) на докторским студијама на Филозофском факултету у Новом Саду.
} 
префиксима у српском језику, а затим смо, као и у већини радова у којима је реч о два или више језика, прибегли контрастивном методу истраживања. Анализа корпуса нам је омогућила да издвојимо језичка средства којима су преводиоци прибегавали преносећи тиме у мањој или већој мери све компоненте значења глагола у руски и енглески језик.

Циљ истраживања је да најпре сагледамо творбене и семантичке особености издвојених глагола а потом да, на основу резултата контрастивне анализе, утврдимо у којој мери је адекватан превод глагола са префиксима $н a$-, над- и $о$ - у руском (као припаднику исте, словенске језичке групе) и енглеском језику (као припаднику германске групе) у односу на српски језик, као и да укажемо на евентуалне преводне еквиваленте који би успешније пренели све компоненте значења глагола у други језик.

Очекујемо да ће анализа потврдити полазну претпоставку и да ће се резултати у српском и руском језику у великој мери подударати, односно да ћемо и у руском језику пронаћи префиксалне глаголе, било да се ради о префиксима на-, над- и $о$ - или неким другим. Што се тиче енглеског језика, с обзиром на то да „префиксација нема у енглеском језику обим и функцију као у српском“ (Novakov 2005: 87) очекујемо да се као преводни еквиваленти јаве синтаксичке конструкције и фразни глаголи, а врло ретко и глаголи са префиксима.

\section{2 Корпус истраживања}

Као извор за прикупљање материјала користили смо роман Иве Андрића На Дрини ћуприја и издвојили глаголе са префиксима на-, над- и о-, а затим их и поредили са њиховим преводним еквивалентима у руском и енглеском језику. Издвојена су укупно 163 префиксална глагола и то: 79 глаголских лексема са префиксом на-, 9 са префиксом над- и 75 глагола са префиксом $о$-. Процентуално представљено, глаголске лексеме са префиксом на- у корпусу заузимају $48 \%$, са префиксом o- 46\%, док глаголи са префиксом над- чине свега 5,5\% корпуса. Иако су анализом обухваћени сви глаголи пронађени у корпусу, у наставку рада ћемо издвојити само неке од типичнијих примера и детаљно их анализирати. 


\section{3 Префиксачија глагола}

Иако су глаголи врста речи у којој префикси имају најширу и најразноврснију примену, овом темом се ипак није бавило много аутора. Клајн је најдетаљније обрадио тему глаголске префиксације (2002: 239-301), апострофирајући и своје претходнике: И. Грицкарт, Московљевић (мешање префикса пре- и при-, 1934), М. Стевановић (русизми типа замаскирати, 1952), М. Ивић (1982), Кантор (префикси о- и об-, 1984), Терзић А. (глаголи на пона- у руском и српском, 1997) и Д. Кликовац (значење префикса раз-, 1998) (Клајн 2002: 240).

Префиксална творба подразумева грађење изведених речи путем припајања префикса творбеној бази. За префиксацију је карактеристично да се творбени формант не додаје на основу, већ на граматички формирану реч, због чега речи добијене префиксалном творбом увек остају у оквиру исте врсте речи као и мотивне речи. Речи настале префиксалном творбом се у српском језику називају префиксалне творенице, односно префиксали (Клајн 2002: 239). ${ }^{2}$

С обзиром на то да префиксалне творенице увек остају у оквиру исте врсте речи, приликом творбе глагола овим творбеним начином као мотивне речи се појављују само глаголи. Клајн (2002) издваја следеће две функције које префикс као творбени формант може имати приликом префиксалне творбе глагола:

1. Промена граматичког значења вида глагола (додавањем префикса глаголи несвршеног вида се претварају у глаголе свршеног вида (писати написати, читати - прочитати).

2. Модификација лексичког значења (додавањем префикса се не мења само вид глагола, већ се уносе и додатне нијансе значења (писати преписати, описати, исписати). ${ }^{3}$

\footnotetext{
${ }^{2}$ В. Клајн (2002: 239-301), Стевановић (1986: 434-450), Шелякин (1983: 113).

${ }^{3}$ Клајн наводи 24 глаголска префикса карактеристична за српски језик: до-, за-, из-, мимо-, на-, над-, нај-, о-, об-, од-, па-, по-, под-, пре-, пред-, при-, про-, против-, раз-, c-(ca-), cy-, cynpom-, y-, yz- (2002: 239-301).
} 


\section{2. АНАЛИЗА КОРПУСА}

Контрастивна анализа нам је омогућила да упоредимо префиксалне глаголе српског језика са њиховом преводним еквивалентима у руском и енглеском језику обраћајући при том пажњу на то да ли они у потпуности преносе одговарајући семантички садржај. Уколико то није случај, покушали смо да понудимо одређени преводни еквивалент који би у датом примеру боље одговарао и тачније пренео све компоненте значења глагола. У даљем раду наведени су неки од типичнијих примера контекстуалне употребе глагола са префиксима на-, над- и $о$-. За проверу значења преводних еквивалената користили смо следеће једнојезичне речнике: Речник српскога језика Матице српске, Речник српскохрватског књижевног и народног језика САНУ и Словарь русского языка Ожегова. Такође, користили смо и двојезични Руско-српски речник у редакцији Богољуба Станковића, док смо за проверу значења енглеских глагола користили интернет портал Оксфордског речника. ${ }^{4}$

\section{1 Глаголска префиксаиија префиксом на-}

Глаголске лексеме са префиксом на- поделили смо на три пододељка на основу основних значења која овај префикс има приликом творбе глагола (Клајн, 2002: 257) и за свако значење посебно издвојили смо неколико детаљно анализираних типичнијих примера из корпуса.

\subsection{1 Просторно значење}

Просторно значење имају глаголи којима се исказује значење додавања, слагања или повезивања (навући, натаћи, набити, нанети, наслагати, натоварити, натрпати), односно продужетка и наставка (наставити), али и глаголи којима се означава случајан контакт са препреком на путу (наићи, налетети). Међутим, глагол наићи може бити употребљен и у значењу ‘доћи, доспети, стићи’ (уп. пр. (3)). Такође, у ову групу Клајн (2002: 257) уврштава и глаголе са радњом која се врши на некој површини (написати) и оне који означавају нагло кретање већег броја живих бића као што је глагол навалити у једном од својих значења.

\footnotetext{
${ }^{4}$ www.oxforddictionaries.com.
} 
1) а) ...али ту су се, све до 1878 . године, вешале или набијале на колац главе свих оних који су ма с кога разлога бивали погубљени... (с. 10)

б) ...здесь же в воротах, вплоть до 1878 года, вешали и насаживали на кол головы несчастных, в силу тех или иных причин преданных казни... (с. 6)

в) ...but there too, right up to 1878 , hung or were exposed on stakes the heads of all those who for whatever reason had been executed... (c. 19)

Као еквивалент српског глагола набијати у руском језику је употребљен глагол са истим префиксом на- (насажсивать) истог значења. ${ }^{5}$ Међутим, у енглеском језику је употребљен глагол $\boldsymbol{e x p o s e ~ к о ј и ~ н е м а ~ у ~ с в о м ~}$ значењу компоненту стављања, најбијања нечега на нешто с обзиром на то да ја његово значење дефинисано као 'make (something) visible by uncovering it'. Међутим, уколико узмемо у обзир стилску и експресивну вредност коју лексеме имају, можемо закључити да при преводу на енглески језик ипак ништа није изгубљено.

2) a) Наравно, нико од њих није знао зашто онако смешно поскакује и набада с ноге на ногу и нико није добро видео оне опекотине од верига које су му ишле око груди као велики каишеви, а преко којих су му навукли кошуљу и гуњ. (с. 40)

б) Никто не знал, конечно, отчего он так смешно подпрыгивает, еле касаясь земли ногами, никто не видел следов ожогов от цепей, опоясывавших его грудь широкими полосами, поверх которых были натянуты рубаха и грубошерстный гунь. (с. 23)

в) Naturally, none of them knew why he hopped in so droll a manner and took abrupt little steps, and none of them could see the burns from the chains which crossed his chest like great belts, for his shirt and cloak hid them. (c. 47)

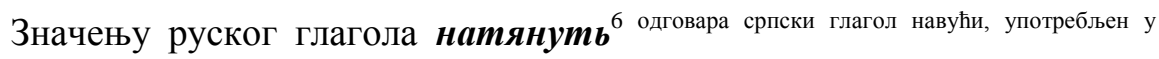
примеру (2)

(2), али у енглеском примеру уопште немамо глагол са истим или

5 Уп. набити: 'насадить, -ажу, -адишь, -адят; -аженный сврш. 4. разг. набити, натући; -шапку натући капу’ (РСР: 392).

${ }^{6}$ УП. натянуть - 'разг. навући; - на себя одеяло - навући на себе ћебе' (РСР: 398). 
сличним значењем с обзиром на то да је употребљен глагол hide ('put or keep out of sight') који се односи на опекотине. У преводу на енглески језик акценат је стављен на то да кошуља скрива опекотине на грудима, док само навлачење кошуље није описано.

3) а) Једне јесени, има од тада око четрнаест година, наишао у хан неки странац. (с. 151)

б) Однажды осенью, лет что-нибудь с четырнадцать назад, на постоялом дворе появился незнакомец. (с. 84)

в) One autumn, some fourteen years before, a stranger had come to the inn. (c. 145)

У примеру (3) употребљен је глагол наићи са значењем 'доћи, доспети, стићи' (РСАНУ: 745), док су у руском и енглеском употребљени глаголи появиться и соте чија значења у овом контексту одговарају поменутом значењу глагола наићи.

\subsection{2 Значење степена остварења радње}

Значење степена остварења радње омогућује поделу глагола са префиксом на- на три групе, и то: на глаголе код којих је радња започета или у мањој мери остварена (нагристи, наслутити, напрснути, назирати), на глаголе код којих је радња остварена у приличној мери или завршена (нагомилати, насећи, научити, напунити, начинити) и на глаголе јаче сативности у значењу „до миле воље“, „до крајњих граница“ (најести се, наситити се, напити се, нагледати се, наслушати се, находати се, надисати се, начудити се).

1) а) Хлеб се месио у наћвама, кафа пекла у оџаку, рубље парило у чабровима и прало у 'лукшији' која женама нагризе и израњави прсте; ткало се и везло на становима и ђерђефима. (с. 141)

б) Тесто месили в квашнях, кофе поджаривали на очаге, белье кипятили в ушатах и стирали в золе, разъедающей руки женщин; ткали и вышивали на станках и пяльцах. (с. 79)

в) Bread was still mixed in kneading troughs, coffee roasted on the hearth, clothes steamed in coppers and washed with soda which hurt the women's fingers; they still span and wove on tambours and hand-looms. (c. 136) 
У примеру (1) у српском језику употребљен је глагол са префиксом на- нагристи у значењу 'изјести, ојести (рану и сл.)' (РМС: 743), док је у руском језику његов еквивалент са истим значењем глагол са префиксом разpaзъедать (уп. 'разједати, нагризати (о киселини итд.)' (РСР: 720). У енглеском језику имамо глагол без префикса hurt, чије значење не одговара у потпуности српском еквиваленту с обзиром на то да је значење овог глагола 'cause pain or injury to'.

2) а) Ни наслутити се није могло на колико је стао, али је било врло вероватно, да има више од двадесет и осам; прво, јер он вечерас на ниским бројевима не остаје и друго, јер има пет карата. (с. 156)

б) Невозможно было угадать, на чем он остановился, однако весьма вероятно, что он набрал больше двадцати восьми: во-первых, сегодня он в недоборе не сидел, а во-вторых, у него пять карт. (с. 87)

в) He was unable to get any idea at how many the stranger had stopped, but it was exceedingly likely that he had more than twenty-eight; firstly, because all evening he had never stopped at low scores and secondly, because he had five cards. (c. 150)

Као еквивалент српском глаголу наслутити ('предосетити; предвидети: - догађаје') (РМС: 779), у руском језику кориштен је глагол са префиксом $y$ - yzaдать истог значења, ${ }^{7}$ док је у енглеском језику употребљена конструкција get any idea са истим значењем.

3) а) Тако је певао Миле у освит дана док није насекао и окресао врљике због којих се испео у шумарак... (с. 86)

б) Так распевал Миле на рассвете, пока не нарубил достаточно веток и дров, за которыми и ходил в рощу... (с. 49)

в) So sang Mile at the break of day until he had cut and trimmed the branches for which he had come. (c. 88)

Еквивалент глаголу насећи у руском језику је глагол са истим префиксом нарубить са истим значењем, ${ }^{8}$ док је у енглеском језику

\footnotetext{
7 УП. 'погодити шта, досетити се чега: - чью мысль - погодити чију мисао' (РСР: 877).

${ }^{8}$ УП. 'насеһи. нацепати' (РСР: 391).
} 
употребљен глагол без префикса cut чије значење нема ту кумулативну компоненту (уп. 'маke an opening, incision, or wound in (something) with a sharp-edged tool or object').

4) а) ...које су дошле из далеких села, да их испрате, да их се још једном нагледају, да се наплачу и накукају, и да им успут покуче још последњу понуду и милошту. (с. 180)

б) ...пришедшие сюда из дальних сел, чтобы проводить их, в последний раз обласкать взглядом, оплакать и осыпать благословениями и напутствиями перед разлукой. (с. 101)

в) ... who had come from distant villages to say farewell, to see them for the last time, to weep, to wail and to give them some last gift or final sign of love. (c. 170)

Јача сативност у значењу „до миле воље“, „до крајњих граница“ у српском и руском језику је у корпусу изражена повратним глаголима са префиксима $н a-{ }^{9}$, док је у енглеском језику употребљена конструкцијама глагол + fill / enough. Међутим, као еквивалент глаголу нагледати ce у енглеском је употребљен глагол see, а у руском језику фраза обласкать взглядом које немају компоненту сативности. ${ }^{10}$ Српски глагол наплакати се на руски је преведен глаголом са 'префиксом о- оплакать, чије би значење више одговарало значењу српског глагола оплакати. ${ }^{11}$ Такође, ни енглески глагол weep са значењем 'shed tears' нема компоненту сативности. Глагол накукати се, кога немамо при преводу на руски језик, у енглеском је изражен глаголом wail без сативног значења ('utter a wail').

\subsection{3 Значење повећања обима у којем се радња испољава}

Стевановић (1986: 438) издваја и значење повећања нечега где пре свега мисли на повећање запремине, обима или висине и то су глаголи као, на пример, надоћи, надолазити, набујати.

\footnotetext{
${ }^{9}$ Уп. најести се, начудити се, напити се, находати се, наслушати се; наесться, наудивляться, находиться, наслушаться, напиться.

10 Уп. обласкать је 'бити срдачан, љубазан према коме, указати наклоност коме' (РСР: 441) и see 'perceive with the eyes; discern visually' (oxforddictionaries.com).

${ }^{11}$ Уп. оплакать - 'оплакати, ожалити' (РСР: 469).
} 
1) a) А кад је после тако сушног лета једне јесени стала овако да надолази Дрина и да прети општа поплава... (с. 75)

б) И когда однажды осенью после засушливого лета вода в Дрине стала прибывать, угрожая наводнением... (с. 43)

в) When one autumn, after such a dry summer, the Drina began to rise and threaten a general flood... (c. 79)

2) а) Дрина је надошла и замутила се. (с. 111)

б) Дрина вздулась и потемнела. (с. 63)

в) The Drina rose and grew angry. (с. 111)

У оба наведена примера српски глаголи надоћи / надолазити преведени су на енглески глаголом без префикса rise ca истим значењем 'move from a lower position to a higher one; come or go up'. У руском језику у примеру (1) употребљен је глагол са префиксом $n p u$ - прибывать, ${ }^{12}$ a у примеру (2) глагол са 'префиксом вз- вздуться истог значење повећања нечега (уп. РСР: 76).

\section{2 Глаголска префиксаиија префиксом над-}

У овом одељку смо упоредили глаголе са префиксом над- у српском језику са њиховим преводним еквивалентима у руском и енглеском језику. Издвојили смо неке од најтипичнијих примера ради детаљније анализе. У складу са Клајновим запажањем (Клајн, 2002: 259), глаголи у чијој је творбеној структури префикс над- и његова обезвучена варијанта нат- могу имати просторно значење и значење супериорности, надмоћи и превазилажења.

\subsection{1 Просторно значење}

Глаголи са 'префиксом над- означавају радњу која се усмерава или врши изнад нечега (наднети, надносити), али и глагол надзирати са метафоричким значењем.

\footnotetext{
${ }^{12}$ Уп. ‘повећавати се, расти; надолазити; пр. вода надолази’ (РСР: 635).
} 
1) а) Наднео се над малишана и опсовао му баку, од милоште, а дете је мирно гледало његово крупно лице са великим плавим очима и широком, риђом брадом. (с. 327)

б) И чертыхнулся в умилении, нагнувшись над малышом, а тот бестрепетно смотрел на крупное лицо священника с большими синими глазами и окладистой рыжей бородой. (с. 184)

в) He bent over the baby and called it little baby names, while the child looked up calmly at the huge face with its big blue eyes and broad reddish beard. (c. 298)

У преводу на руски и енглески као еквиваленти српског глагола наднети се су употребљени глаголи нагнуться и bend истог значења. ${ }^{13}$ Значење надношења над нечим које је код српских глагола у овом случају изражено префиксом над- и предлогом над након глагола, у руском је изражено само предлогом над (над малышом), а у енглеском језику предлогом over (over the baby).

2) a) Испод њега је био слободан пут за кола, коње и пешаке, али се одозго, са спрата на ком ће спавати стражари и на који су водили ненаткривени смрчеви басамаци, могло увек и надзирати свакога ко прође... (с. 82)

б) Под ним оставался свободный проезд и проход для телег, всадников и пеших, но с верхнего этажа надстройки, где находились караульные и куда вела наружная лестница из сосновых досок, можно было видеть каждого прохожего... (c. 47)

в) Beneath it there was a free passage for carts, horses and pedestrians, but from above, from the floor on which the guards slept and to which led an uncovered stairway, it was possible to inspect ail who passed... (c. 8485)

У примеру (2) у српском језику имамо префиксални глагол надзирати, чије је значење у РМС описано као '1. имати увид у нечији рад, у неку делатност, вршити надзор над неким, над нечим; надгледати,

\footnotetext{
${ }^{13}$ Нагнуться 'нагнути се, сагнути се, савити се' (РСР: 373); 'shape or force (something straight) into a curve or angle' (oxforddictionaries.com).
} 
контролисати (некога, нешто). 2. водити бригу о некоме, нечему, пазити, надгледати. 3. посматрати, проматрати, осматрати' (РМС: 747). Као еквивалент у руском језику употребљен је глагол без префикса видеть, чије значење одговара српском глаголу видети, а не надзирати (уп. РСР: 79). У преводу на енглески употребљен је глаголи без префикса inspect чије значење одговара значењу српског глагола надзирати (уп. inspect - 'look at (someone or something) closely, typically to assess their condition or to discover any shortcomings').

\subsection{2 Апстрактно значење супериорности, надмоћи и превазилажења}

Ово значење подразумева да се радња остварује у већем, јачем степену у односу на исту радњу коју обавља други вршилац, изражавајући тиме супериорност (надмудрити, надживети). С друге стране, уколико се ради о повратним глаголима, они могу имати у значењу и компоненту такмичења (надвикивати се, надбијати се). Такође, треба истаћи да и глагол надзирати може имати нијансе овог значења уколико се у одређеном контексту односи на некога ко је метафорично на вишој позицији.

1) а) Сад је погледао мало дуже и смелије, и што је најчудније, погледала је и она њега, кратким али слободним погледом, искоса, мало насмејано, мало лукаво, али оним ведрим лукавством којим деца надмудрују једно друго у игри. (с. 167)

б) На этот раз он дольше задержал на ней свой взгляд, к удивлению своему обнаружив, что и она посмотрела на него, озарив его открытым, смелым взглядом смеющихся глаз, как бы вызывающих его с детским лукавством посостязаться с ней в хитроумной забаве. (c. 93)

в) This time he looked at her a little longer and more boldly, and what was even more wonderful she too looked at him. a short but candid glance, with a sort of half-smile, almost cunningly but with that innocent cunning with which children get the better of one another at their games. (c.159)

Значење глагола надмудрити у РМС је: ‘а. показати, испољити више мудрости од другога, надмашити, превазићи некога мудрошћу, памећу. б. изиграти, преварити некога служећи се мудрошћу, лукавством, вештином, надмашити лукавством, вештином' (РМС: 748). У руском језику као еквивалент употребљен је глагол состязаться са 'префиксом по- који има 
значење такмичења као српски глагол надмудрити, ${ }^{14}$ док је у енглеском употребљена конструкција get the better истог значења. ${ }^{15}$ Међутим, треба истаћи да оваква решења не омогућују да се у потпуности пренесе садржај српског глагола с обзиром на то да при преводу на оба језика недостаје компонента која нам говори о учешћу мудрости, памети и ума приликом такмичења.

2) а) Ту има много старих ратничких нагона, али пробуђених у невреме, збуњених и обезглављених у овом двобоју у коме се изнад њихових глава надбијају две артиљерије, обе хришћанске. (с. 319)

б) Здесь кипят несвоевременно пробужденные старые воинственные страсти, несколько обесцененные, правда, артиллерийским поединком двух христианских армий, ведущимся у них над головой. (с. 179)

в) Much of the old warlike instincts remained but they had been awakened in an evil hour, embarrassed and pointless in face of that duel going on over their heads in which the artillery of the two sides, both Christian, were taking part. (c. 291)

У примеру (2) у српском језику кориштен је глагол надбијати се са значењем ‘побеђивати, надјачавати, надвладавати' (РМС: 745). Међутим, у примеру у руском језику је употребљен партицип глагола вести (ведущийся), а у енглеском глагол take part који су еквиваленти српским глаголима водити, одвијати се, учествовати и немају у свом значењу ту компоненту такмичења која је присутна у српском глаголу надбијати се. Међутим, преводиоци су на оба језика значење такмичења изразили лексички, речима артиллерийская поединка и duel, с обзиром на то да 'атриљеријски двобој' подразумева 'такмичење'.

3) а) Све их је надвикивао један тенор који је испрекидано и сувише високо певао старинску песму. (с. 276)

б) Кто-то прерывающимся фальцетом тянул старинную песню. (с. 156)

\footnotetext{
${ }^{14}$ Уп. 'такмичити се, натјецати се, надметати се' (РСР: 809).

15 УП. 'gain an advantage over or defeat (someone) by superior strength or ability' (oxforddictionaries.com).
} 
в) Loudest among them was a tenor who sang in falsetto an ancient song. (c. 254)

Значење глагола надвикивати из примера (3) 'надјачати, надвладати (некога) виком, гласом, викнути јаче од некога, бити гласнији, грлатији од некога' (РМС: 745) у потпуности је пренето у енглески језик фразом loudest among them, док у руском језику у преводу немамо ништа што указује на надмоћност тенора те значење поменутог глагола није изражено при преводу на руски.

\section{3 Глаголска префиксачија префиксом о-}

Глаголе са префиксом $о$ - упоредили смо са њиховим преводним еквивалентима у руском и енглеском језику и издвојили неке од најтипичнијих примера уз детаљнију анализу. Класификација је извршена према значењима која је Клајн издвојио у Твроби речи у савременом српском језику (2002: 260).

\subsection{1 Просторно значење}

Глаголи са просторним значењем означавају радњу која на објекат делује са разних страна или га на неки начин целог обухвата (окружити, окопати, огрејати, окитити, окупити, очарати, ограничити, описати). ${ }^{16}$

Клајн у ово значење убраја и глаголе са значењем уклањања спољног омотача као што је глагол оштетити, али и метафорички употребљен глагол опљачкати (2002: 260). Значење простора на апстрактнијем нивоу срећемо и код глагола оплакати, оговарати. ${ }^{17}$

1) а) На висини од две хиљаде метара, окружен светом разних језика и народности, гледам бескрајност видика и мислим на тебе и минуло лето. (с. 299)

\footnotetext{
16 Првобитно значење видимо у математичкој употреби овог глагола: „круг описан око троугла“ (Клајн 2002: 260).

${ }^{17}$ Код овог глагола префикс има значење 'около', ‘на разним местима'.
} 
б) На высоте двух тысяч метров, окруженный разноязычной и разноплеменной толпой, озирая беспредельные просторы, я думаю о тебе и о прошедшем лете. (с. 169)

в) At a height of 2,000 metres, surrounded by people of various tongues and nationalities, I look at the boundless horizon and think of you and last summer. (c. 274)

Еквививалет српском глаголу окружсити у руском језику је исти глагол са истим префиксом о- окружить (уп. РСР: 466), док је у енглеском то глагол без префикса surround са истим значењем. ${ }^{18}$

2) а) ...чекао их је са обе стране поређан варошки свет, који је изашао да испрати регруте и да их оплаче као да их воде на стрељање. (с. 181)

б) ...где ее ожидала плотная стена горожан, высыпавших на проводы рекрутов, причитая над ними, точно над приговоренными к расстрелу. (с. 102)

в) ...all the townspeople were awaiting them, drawn up on each side of the road, in order to see the recruits and to weep for them as if they were being taken away to be shot. (c. 171)

Еквивалент српском глаголу оплакати у руском језику био би исти глагол са истим префиксом оплакать, међутим у овом случају у примеру (2) употребљен је глагол причитать чије је значење интензивније од значења поменутог глагола. ${ }^{19}$ Значење енглеског глагола без префикса weep 'shed tears' одговара значењу српског глагола оплакати.

\subsection{2. Значење изазивања појаве особине и значење стана}

У ову групу смо сврстали глаголе са придевским основама који имају значење изазивања појаве одређене особине, а то су у првом реду каузативни глаголи, док нам медијални глаголи описују одређена стања (ојачати, ослабити, освежити (се), охрабрити, осладити, обогатити (се),

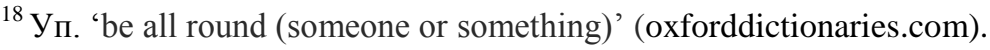

${ }^{19}$ Уп. ‘кукати, јадиковати, нарицати, запевати, лелекати’ (РСР: 657).
} 
олакшати, остарити, омршати, оглухнути, оздравити, оболети, очврснути).

1) а) Пун је и тежак, жут у лицу; око очију тамни колутови који се спуштају до половине образа; вид му је ослабио... (с. 292-293)

б) Он погрузнел, обрюзг и пожелтел лицом; темные круги, спускаясь к середине щек, залегли под глазами; зрение ослабло... (с. 165)

в) Now he was heavy and ponderous and yellow in the face; dark rings about his eyes stretched half way down his cheeks; his eyes had grown weak... (c. 268)

У примеру (1) у српском и руском језику су употребљени исти глаголи са префиксом о- (ослабити, ослабить) док је у енглеском језику то фраза grow weak истог значења 'become gradually or increasingly’.

2) а) С временом, девојка се прибрала, ојачала, оздравила и преобразила се, брзо и природно како само младост може. (с. 301)

б) И, уступая здоровому зову юности, на глазах ожсвала и хорошела, неузнаваемо расцветая, девушка. (с. 170)

в) In time the girl came to herself, grew stronger and healthier, and was transformed, quickly and naturally, as only youth can be. (c. 276)

У примеру (2) употребљена су два глагола са префиксом $o$-: ојачати и оздравити, која су у енглеском језику пренесена фразом grow stronger и grow healthier истог значења. ${ }^{20}$ Међутим, у руском језику употребљени су глагол са префиксом $о$ - оживать ${ }^{21}$ који, употребљен у пренесеном значењу, има исто значење као српски глагол ојачати и глагол без префикса хорошеть ${ }^{22}$ који у књижевном стилу и одређеном контексту може одговарати значењу српског глагола оздравити. У овом случају при преводу на руски могли су се употребити глаголи са префиксима $о$ - истог значења: окрепнуть и оздоровить.

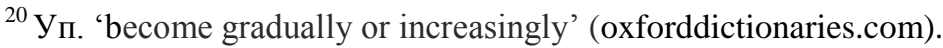

${ }^{21}$ Уп. 'стать полным сил, проявиться в прежней силе' (СРЯ 2008: 1113).

${ }^{22}$ УП. 'становиться лучше, привлекательнее (книжн.)' (СРЯ 2008: 2178).
} 
3) а) Јамак тада оглухне и на оно здраво ухо или просто оде за Град да обиђе своју њиву. (с. 14)

б) Ямак становился глух и на второе, здоровое ухо или вовсе уходил за Старый град обрабатывать свой надел. (с. 8)

в) Jamak then became deaf even in his one sound ear or simply went up to the Fortress to work in his field. (c. 23)

У примеру (3) глагол оглухнути у српском језику је у руском и енглеском језику изражен конструкцијом фазни глагол (становиться, become) + придев (глуx, deaf) што одговара значењу српског глагола оглухнути, односно постати глув.

4) а) Последњих година живота он је омршао и погурио се, некако потамнео и огрубео у лицу. (с. 65)

б) В последние годы жизни визирь $y c o x$ и сгорбился, как-то потемнел и погрубел лицом. (с. 38)

в) In the last years of his life he had grown thin and bowed, almost withered and coarser in feature. (c. 70)

Глагол омриати је у руском језику изражен глаголом са префиксом $y$ - усохнуть са значењем 'усахнути, сасушити се' (РСР: 899), иако би потпуни еквивалент српском глаголу био гл. похудеть ('омршавети, смршати, ослабети') (РСР: 620). У енглеском је овај глагол изражен конструкцијом коју смо већ помињали у претходним примерима grow thin.

\subsection{3 Каузативни глаголи са значењем стања}

Каузативни глаголи који подразумевају довођење у одређено стање су: оженити, обрукати, док као медијалне глаголи са значењем стања можемо издвојити глаголе окишити и олистати. Глаголи ове групе имају именичке основе.

1) а) Слушај ти, ако не буде све како треба и ако ме обрукаш пред светом, не излаз те ми пред очи ни ти ни овај цигански брабоњак; потопићу вас у Дрину, као слепу штенад. (с. 40)

б) Слушай, ты, если что-нибудь будет не так, если опозорите меня перед всем честным миром, не показывайтесь мне на глаза ни ты, ни 
этот цыганский ублюдок: потоплю вас в Дрине, как слепых кутят. (с. 23)

в) Listen you! If everything is not as it should be and if you disgrace me in public, neither you nor your bastard of a gipsy will ever appeal before me again, for I will drown you both in the Drina like a pan oi blind puppies.' (c. 47)

Глагол обрукати је у руском језику изражен глаголом са истим префиксом 0 - опозорить истог значења, ${ }^{23}$ док је у енглеском то глагол са префиксом dis- disgrace. $^{24}$

2) а) Земља набуја и све што је у њој још живо исклија, напупи, олиста, процвате, и понесе стоструким родом. (с. 290)

б) Вспучилась земля, и все, что в ней было живого, набухло, взошло, оделось листьями, распустилось, зацвело и уродило сторицей. (с. 164)

в) The earth swells and everything in it bursts vigorously into buds and leaves and blossoms and brings forth fruit a hundredfold. (c. 266)

Значење глагола олистати из примера (2) је у руском и енглеском језику изражено описно конструкцијом одеться листьями и burst into leaves. $^{25}$

3) а) На клупи, у углу механе, дрема Ћоркан, притискује га сан и влажна топлота и прва ракија; данас је окисао до коже, носећи неке ствари чак на Околишта. (с. 203)

б) В углу на скамье дремлет Кривой, сморенный влажной теплотой и первой чаркой ракии; промок он сегодня до нитки, перетаскивая тяжести на Околиште. (с. 113)

в) On a bench in a corner of the inn Corkan drowsed overcome by fatigue, the moist heat and the first glasses of plum brandy; it was raining cats and dogs. (c. 190)

\footnotetext{
${ }^{23}$ Уп. 'осрамотити, окаљати' (РСР: 469).

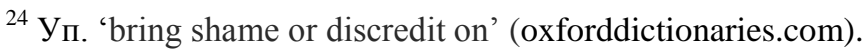

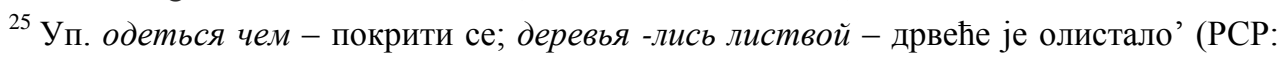
459) и burst 'suddenly begin doing or producing something' (oxforddictionaries.com).
} 
У примеру (3) израз окиснути до коже у руском језику је изражен фразом промокнуть до нитки истог значења (уп. РСР: 674), док је у енглеском такође употребљен фразеологизам rain cats and dogs 'rain very hard'. Међутим, с обзиром на то да је у тексту на српском субјекат һоркан и глаголом се исказује његово стање. у енглеском преводу се, пак, описују временске прилике и Ћоркан изостаје као субјекат, тј. носилац ситуације. Део текста, такође, није ни преведен те можемо рећи да енглески превод није адекватан.

\section{3. ЗАКЉУЧАК}

У раду смо се бавили анализом семантике глаголских лексема у чијој творбеној структури срећемо префиксе на-, над- и $о$ - и класификацију по значењу извршили према значењима која је Клајн издвојио у Творби речи у савременом српском језику (2002). Глаголске лексеме са поменутим префиксима смо прикупили из романа На Дрини ћуприја, а затим смо их путем контрастивне анализе упоређивали са њиховим преводним еквивалентима у руском и енглеском језику с циљем издвајања језичких средстава којима су преводиоци прибегавали преносећи тиме у мањој или већој мери све компоненте значења глагола у руски и енглески језик. Све то нам је омогућило да сагледамо творбене и семантичке особености издвојених префиксалних глагола, као и да на основу резултата контрастивне анализе утврдимо у којој мери је адекватан превод глагола са префиксима нa-, над- и $о$ - у руском (као припаднику исте, словенске језичке групе) и енглеском језику (као припаднику германске групе) у односу на српски језик.

На основу резултата добијених контрастивном анализом, дошли смо до закључка који је потврдио полазну хипотезу, а то је да је знатно већа подударност када се ради о српском и руском језику. То показује и чињеница да су у руском језику као преводни еквиваленти најчешће кориштени глаголи са префиксима, иако то нису увек били префикси над-, на- и о-, већ и многи други као што су: вз-,за-, пере-, по-, при-, раз-,с- / co-, y-, у знатном броју случајева смо ипак имали и поклапања префиксалних форманата. У прилог томе говори и чињеница да се значења глагола са префиксима над-, $н a$ - и $o$ - у српском и руском језику у великој мери поклапају. ${ }^{26}$ При преводу

${ }^{26}$ Уп. Ожегов 2008: 923, 935, 1053 и РГ-1980: 360-361. 
на руски језик смо се сусрели са појединачним случајевима у којима су употребљени глаголи без префикса (видеть, лезть, хорошеть) или се радило о одређеној синтаксичкој конструкцији, односно фрази (скрещивать копья, одеться листьями). Међутим, у енглеском језику се значења реализују на синтаксичком нивоу и врло ретко смо сретали префиксалне глаголе. Наиме, у енглеском језику поред глагола без префикса доминирају фразни глаголи и синтаксичке конструкције (глагол + fill / enough, get the better, loudest among them, going on, grow + придев, become + придев) док префиксалне глаголе срећемо у појединачним случајевима (outlive, disgrace).

На неколико места у корпусу су примећене празнине, тачније одређени глаголи нису преведени на енглески и/ или руски језик и за такве појаве не постоји адекватно објашњење, с обзиром на то да је, осим глагола, у појединим случајевима изостављен и део реченице или, пак, цела реченица, што смо и нагласили код сваког примера посебно. Такође, потрудили смо се и да укажемо на евентуалне преводне еквиваленте који би успешније пренели све компоненте значења глагола у други језик.

Добијени резултати могу своју примену наћи као основа за обимнија истраживања на већем корпусу, чији би циљ био упоредно разматрање творбених и семантичких особености глагола за сваки појединачни глаголски префикс.

\section{СКРАЋЕНИЦЕ}

[PМС]= Вујанић, М., Николић, М. и др. (2011). Речник српскога језика. Нови Сад: Матица српска.

[РСАНУ] = Речник српскохрватског књижевног и народног језика. Београд: CAHУ.

$[С Р Я]=$ Ожегов, С. И. Скворцов, Л. И. (2008). Словарь русского языка: Ок. 60000 слов и фразеологических выражений / С. И. Ожегов. Москва: ООО «Издательство Оникс»: ООО «Издательство Мир и Образование».

$[\mathrm{PCP}]=$ Станковић, Б. (2008). Руско-српски речник/ у редакцији Богољуба Станковића. Допуњено издање. Нови Сад: Прометеј.

[РГ-1980]= Шведова, Н. Ю. (1980). Русская грамматика. Т. 1. Москва: «Наука».

WWW.OXFORDDICTIONARIES.COM 


\section{ИЗВОРИ}

Андрић, И. (2011). На Дрини ћуприја. https://znakovi.files.wordpress.com/ 011/05/ivo-andric-na-drini-cuprija.pdf (02. 05. 2019)

Андрич, И. (1985). Мост на Дрине. Пер. с сербскохорв. А. Д. Романенко. Москва:

Правда.https://imwerden.de/pdf/andrich_most_na_drine_1985_ocr.pdf (05. 05. 2019.)

Andrić I. (1919). The bridge on the Drina. Translated by Lovett F. Edwards. London: Ruskin House, Goerge Allen And Unwin ltd. https://archive.org/details/in.ernet.dli.2015.149540/page/n3/mode/2up_(10. 05. 2019)

\section{ЛИТЕРАТУРА}

Авилова, Н. С. 1976. Вид глагола и семантика глагольного слова. Москва: Наука.

Војводић, Д. 2013. „Вид глагола“. Српска енщиклопедија, том II. (Ур. Ч. Попов, Д. Станић). Нови Сад: Матица српска. Београд: САНУ/ Завод за Уџбенике. Стр. 332-333.

Глођовић, А. 2014. Функиија адвербијалних партикула у енглеским фразним глаголима и ғихови српски преводни еквиваленти. Крагујевац: Филолошко-уметнички факултет: [текст докторске дисертације].

Клајн, И. 2002. Творба речи у савременом српском језику, I део: Слагање и префиксачија. Београд: Завод за уџбенике и наставна средства/ Институт за српски језик САНУ. Нови Сад: Матица српска.

Кликовац, Д. 1998. „О значењу српског глаголског префикса раз(когнитивнолингвистички приступ)“. Наш језик XXXII 3-4, 153-167.

Пипер, П. 1990. „Tertium comparationis у контрастивним и типолошким описима словенских језика“. Kontrastivna jezička istraživanja: simpozijum (Novi Sad, 8. i 9. decembar 1989), 15-23.

Стевановић, М. 1986. Савремени српскохрватски језик. Том І. Фонетика. Морфологија. Београд: ИРО Научна књига.

Шелякин, М. А. 1983. Категория вида и способы действия русского глагола (теоретические основы). Талин: Валгус.

Шелякин, М. А. 2008. Категория аспектуальности русского глагола. Москва: ЛКИ.

Novakov, Predrag. 2005. Glagolski vid i tip glagolske situacije u engleskom $i$ srpskom jeziku. Novi Sad: Futura publikacije. 
Катарина Р. Полић

О ГЛАГОЛЬНЫХ ЛЕКСЕМАХ С ПРИСТАВКАМИ НА-, НАД- И $О$ - В СЕРБСКОМ ЯЗЫКЕ И ИХ ПЕРЕВОДНЫХЭКВИВАЛЕНТАХ В РУССКОМ И АНГЛИЙСКОМ ЯЗЫКАХ

Резюме

В работе сначала анализируются значения глагольных лексем с префиксами на-, над- и o- в сербском языке, затем сравниваются примеры глаголов с данными префиксами в сербском подлиннике (в романе Мост на Дрине Иво Андрича) с их переводными эквивалентами в русском и английском языках. Целью работы является определение степени адекватности перевода сербских глаголов с префиксами на-, над- и о- в русском и английском языках. На основании результатов, полученных в ходе сопоставительного анализа, автор приходит к выводу, что между сербским и русским языками (принадлежащими к одной и той же славянской языковой группе) наблюдается в этом плане намного больше сходств, чем между сербским (и соответственно русским) и английским (принадлежащим к германской языковой группе), в котором глагольные лексемы с упомянутыми префиксами ыражаются синтаксическими конструкциями и фразеологизированными глаголами, а редко глаголами с префиксами.

Ключевые слова: приставки на-, над- и о-, словообразование глаголов, сербский язык, русский язык и английский языки, сопоставительный анализ. 